\title{
Effect of Foliar Spraying with Nano and Natural Materials under Water Stress Conditions on Cotton Leaves Chemical Composition Attia, A. N. ${ }^{1}$; M. S. Sultan ${ }^{1}$; M. A. Emara ${ }^{2}$ and B. W, El-Shazly ${ }^{2}$ ${ }^{1}$ Agronomy department, Faculty of Agriculture, Mansoura University, Egypt. ${ }^{2}$ Cotton Research Institute, Agricultural research Center, Giza, Egypt.
}

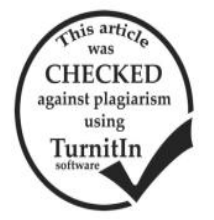

\section{ABSTRACT}

Two field experiments were conducted on a clay soil at El-Gemmeiza Agricultural Research Station, , Egypt during growing 2015 and 2016 seasons, to find out the proper irrigation interval and the effect of Nano and natural materials in reducing the negative effect of water stress on cotton leaves chemical composition of the Egyptian cotton cultivar Giza 86 through study the effect of three Nano-materials treatments (without, $7.5 \mathrm{~g} / \mathrm{L}$ lithovit and $1 \mathrm{~cm}^{3} / \mathrm{L}$ amino mineral) and three natural materials treatments (without, $200 \mathrm{ppm}$ salicylic acid and $5 \mathrm{~cm}^{3} / \mathrm{L}$ humic acid) under three irrigation intervals (every14, 21 and 28 days) as well as their interactions. Each experiment contained three separate experiments represented the three irrigation intervals; i.e. every 14, 21 and 28 days. Also, the combined analysis between the three experiments was done. The two other factors distributed in each experiment in a strip plot design with four replicates, where the horizontal plots were assigned to the foliar of Nanomaterials and the vertical plots contained natural materials treatments. Results showed that: The highest percentages of N, P and $\mathrm{K}$ in leaves were obtained from irrigation interval of 21 days followed by irrigation interval of 28 days. Also, irrigation intervals exhibited significant differences in leaves concentrations of photosynthetic pigments i.e. chlorophyll a and total chlorophyll, total carbohydrates and total sugars in both seasons and chlorophyll $\mathrm{b}$ and carotenoids in the $2^{\text {nd }}$ season only, under irrigation interval of 21 days. The minimum values of leaves proline concentration, peroxidase and phenoloxidase activity in cotton leaves were obtained from irrigated every 21 days which induced favorable conditions and reduces water stress effect. Foliar $\mathrm{CO}_{2}$ as a Nano fertilizer (in the form of lithovit) three times at a rate of $7.5 \mathrm{~g} / \mathrm{L}$ significantly increased percentage of $\mathrm{N}, \mathrm{P}$ and $\mathrm{K}$ in leaves and leaves concentrations of photosynthetic pigments such as chlorophyll a, chlorophyll $\mathrm{b}$, total chlorophyll and carotenoids, leaves total carbohydrates and total sugars contents in both seasons. Also, it significantly decreased leaves proline content, peroxidase and phenoloxidase activity which indicates favorable conditions and reduces water stress effect; however untreated plants recorded the highest values. Foliar feeding with $5 \mathrm{~cm}^{3} / \mathrm{L}$ humic acid three times significantly increased percentage of $\mathrm{N}, \mathrm{P}$ and $\mathrm{K}$ in leaves, values of leaves concentrations of photosynthetic pigments i.e. chlorophyll a, chlorophyll $\mathrm{b}$, total chlorophyll and carotenoids, total carbohydrates and total sugars followed by using salicylic acid as foliar spraying at a rate of $200 \mathrm{ppm}$ and the least values were obtained from untreated plants (without natural materials application) in both seasons. In contrary, applying 5 $\mathrm{cm}^{3} / \mathrm{L}$ humic acid results recorded the lowest values of proline content, peroxidase and phenoloxidase activity in leaves in both seasons followed by applying salicylic acid at a rate of $200 \mathrm{ppm}$. Plants irrigated every 21 days which received $\mathrm{CO}_{2}$ as a $\mathrm{Nano}$ fertilizer at a rate of $7.5 \mathrm{~g} / \mathrm{L}$ in combination with $5 \mathrm{~cm}^{3} / \mathrm{L}$ humic acid led to a significant increase in $\mathrm{P}, \mathrm{K}$, total sugars and total carbohydrates concentrations in leaves compared to the other interaction treatments; however, cotton plants irrigated every 14 days without application with Nano or natural treatments produced the lowest concentrations. Also, plants irrigated every 21 days which received $\mathrm{CO}_{2}$ as a Nano fertilizer at a rate of $7.5 \mathrm{~g} / \mathrm{L}$ in combination with $5 \mathrm{~cm}^{3} / \mathrm{L}$ humic acid gave the lowest values of proline content, peroxidase and phenoloxidase activity in cotton leaves in the first season, which induced proper conditions for plant growth and reflect on reduce water stress effect. It could be concluding the irrigation cotton plants every 21 days in combination with foliar $\mathrm{CO}_{2}$ as a Nano fertilizer (in the form of lithovit) at a rate of $7.5 \mathrm{~g} / \mathrm{L}$ and foliar feeding spraying with 5 $\mathrm{cm}^{3} / \mathrm{L}$ humic acid three times (at the squaring stage, flowering initiation and at the top of flowering) to overcome the water shortage at the end of water sources (canals) as well as when water scarcity becomes wide spread, where this combination is the best treatment for good leaves chemical composition under the conditions of El-Gemmeiza location.

Keywords: Cotton varieties, Foliar spraying, Nano and natural, Humic acid, materials, Water stress.

\section{INTRODUCTION}

Egyptian cotton occupies a privileged position among field crops, it is a strategic crop plays an important role in the Egyptian national income for three main reasons:(1)- It is not only for high-quality recipes, but also for the stability of its presence overseas markets for long periods given stable textile industries based upon those markets in the first crop exporting to fame in the markets, (2)- It is a mainstay of Egypt's most important industries (textile industry, textile and garments) in addition to its important for the production of food and oil, earning sources and (3)-The cotton production is very important for its socio-economic value in the country.

It is well known that water is an essential component of plant life Therefore, if the water content falls below the optimum level many of the physiological activities are impaired. However, the plants use water for transpiration usually account $99 \%$ of the water use by the plant where transpiration generally occurs whenever stomata are open. The plants extract water from the soil to replenish water that lost by transpiration. The equilibrium important between water absorption and water lost by transpiration is very important to keep the cotton plants avoid the water stress condition through the day light. Water stress due to lack of water around the roots or high temperature causes plant water deficits, that reduce cell 'turgor causing closure of stomata and reduction in cell enlargement which reducing both of leaf surface and the photosynthesis per unit of leaf area. Further reducing results in the damage of photosynthetic machinery. Water stress is the most influential factor affecting crop yield particularly in irrigated agriculture in arid and semi-arid regions, it is necessary to get maximum yield in agriculture by using available water in order to get maximum profit from unit area because existing agricultural land and irrigation water are rapidly diminishing due to rapid industrialization and urban development. The use of irrigation strategies is fundamental to save more water without putting at risk crop yield (Jalota et al., 2006 and Pereira et al., 2009). Tang et al. (2005) obtained excellent results in cotton 
yield by managing water deficits during plant development and saving water during irrigation. Saving water in irrigated areas is the definition of the suppression of irrigation correctly promoting the physiological seasoning of plants without compromising yield.

Optimizing irrigation management due to water scarcity together with appropriate crops for cultivation is highly in demand; the cost of irrigation pumping and inadequate irrigation scheme capacity as well as limited water sources is among the reasons that force Egypt to reduce irrigation applications. Several strategies have been proposed to alleviate the degree of cellular damage caused by abiotic stress and to improve crop tolerance. Among them, the applications of natural materials such as humic acid and salicylic acid.

The potential of the humic acid to supply nutrients; hormones and capable of mobilizing nutritive elements from no usable form to usable form through biological processes which simulates cell division and enlargement as well as the synthesis of protein, nucleic acid in addition, to its capability in induction of endogenous hormones like $\mathrm{GA}_{3}$ and IAA.

El-Sayed (2012) reported that humic acid (in the form of actosol) as a constituent of organic matter is considered to be relatively rich nutritional source, where it contained the essential elements needed for cotton plant growth (N, P, K, Mg, Ca, Cl, Fe, $\mathrm{Zn}, \mathrm{Mn}, \mathrm{Cu}$, and B). Applying humic acid as foliar spraying at a rate of 5 $\mathrm{cm}^{3} / 1$ three times at 40,55 and 70 days from sowing increase the efficiency of mineral NPK fertilizers rates and led to positive effect on growth.

Lithovit (a Nano $\mathrm{CaCO}_{3}$ ) has been given much attention as a natural safety fertilizer which releases $\mathrm{CO}_{2}$ which reflected in improving net photosynthesis and causes various promoted effect on plants. Attia et al. (2016) reported that foliar $\mathrm{CO}_{2}$ as a Nano fertilizer in the form of lithovit enhanced cotton leaves chemical composition.

The natural and Nano-materials as foliar spraying through the growing season of cotton are a good tool to increase cotton plant tolerance and get the cotton plant to survive the water stress periods to continue vegetative and fruiting stages successfully. Every effort which contributes to avoid water stress and economic production of the crop should support cotton's position.

The objective of this study was to assess the effect of irrigation intervals and determine the proper interval and the probability of reducing the effect of water stress by using Nano materials i.e. lithovit (a Nano $\mathrm{CaCO}_{3}$ ) and amino mineral as foliar application or natural materials i.e. humic acid and salicylic acid as foliar application or together with regard to the leaf chemical composition of the Egyptian cotton cultivar Giza 86 under the environmental conditions of ElGharbia Governorate and when water scarcity becomes wide spread.

\section{MATERIALS AND METHODS}

Two field experiments were conducted at ElGemmeiza Agricultural Research Station, El-Gharbia Governorate, Egypt in 2015 and 2016 seasons, to find out the proper irrigation interval and the effect of Nano and natural materials in reducing the negative effect of water stress through study the effect of three Nanomaterials treatments (without, lithovit and amino mineral) and three natural materials treatments (without, salicylic acid and humic acid) under three irrigation intervals (every14, 21 and 28 day) as well as their interactions on cotton leaves chemical composition of the Egyptian cotton cultivar Giza 86. Each experiment contained three separate experiments represented the three irrigation intervals; i.e. every 14, 21 and 28 days. Also, the combined analysis between the three experiments was done. The two other factors distributed in each experiment in a strip plot design with four replications, where the horizontal plots were assigned to the foliar of Nano-materials as follows: Without (control), foliar $\mathrm{CO}_{2}$ as a Nano- fertilizer in the form of lithovit $(7.5 \mathrm{~g} / \mathrm{L})$ and Amino mineral $\left(1 \mathrm{~cm}^{3} / \mathrm{L}\right)$. The vertical plots contained natural materials treatments of: Without, salicylic acid (200 ppm) and humic acid (5 $\mathrm{cm}^{3} / 1$ water). Nano and natural materials with the mentioned concentrations were sprayed three times (at the squaring stage, flowering initiation and at the top of flowering). The irrigation treatments were start after the second irrigation.

Natural CO2 as a Nano-foliar fertilizer in the form of Lithovit ${ }^{\circledR}$ (a Nano CaCO3) is a new top quality Nano technological fine powder created by tribodynamic activation and micronization. The different components of Lithovit ${ }^{\circledR}$ were illustrated in Table 1.

Table 1. Main components of Lithovit ${ }^{\circledR}$

\begin{tabular}{lccc}
\hline Components & Value (\%) & Components & Value (\%) \\
\hline Calcium carbonate & 79.19 & Sulphate & 0.33 \\
$\mathrm{~N}$ & 0.06 & $\mathrm{Fe}$ & 1.31 \\
$\mathrm{P}$ & 0.01 & $\mathrm{Zn}$ & 0.005 \\
$\mathrm{~K}_{2} \mathrm{O}$ & 0.21 & $\mathrm{Mn}$ & 0.014 \\
Magnesium carbonate & 4.62 & $\mathrm{Cu}$ & 0.002 \\
Selisium dioxide & 11.41 & Clay & 0.79 \\
\hline
\end{tabular}

Amino mineral fertilizer product manufactured by Nanotechnology contains major and micro elements with amino acids as shown in Table 2.

Table 2. Main components of amino mineral

\begin{tabular}{lccc}
\hline Components & $\begin{array}{c}\text { Value } \\
(\mathbf{\%})\end{array}$ & Components & $\begin{array}{c}\text { Value } \\
(\mathbf{\%})\end{array}$ \\
\hline Amino acids & 5 & $\begin{array}{c}\text { Micro elements: } \\
\text { Boron }\end{array}$ & \\
Algae extract & 5 & $\begin{array}{c}\text { Molybdenum } \\
\text { Iron }\end{array}$ & 10 \\
Vitamins & 1 & Zinc & \\
Potassium oxide & 3 & Manganese & \\
Nitrogen & 8 & Cobalt & \\
Phosphor $\mathrm{P}_{2} \mathrm{O}_{5}$ & 5 & Copper & \\
\hline
\end{tabular}

Humic acid is the active ingredient of actosol product, the natural organic fertilizer, commercially known as potash actosol and manufactured by ARCTICK Inc, Chentilly, VA, USA. The different constituents of humic acid (actosol) were illustrated in Table 3. 
Table 3. Main components of humic acid (actosol) used in the study.

\begin{tabular}{lcclc}
\hline Components & & Value & Components & Value \\
\hline $\mathrm{P}^{\mathrm{H}}$ & & 7.6 & Total chloride $\%$ & 0.50 \\
Humic acid $\%$ & 20 & Total iron ppm & 100 \\
Total nitrogen $\%$ & 1 & Total zinc ppm & 10 \\
Total phosphorus $\%$ & 5 & Total manganese ppm & 10 \\
Total potassium \% & 6 & Total copper ppm & 10 \\
Total magnesium $\%$ & 0.07 & Total boron ppm & 7 \\
Total calcium $\%$ & 0.08 & \\
\hline
\end{tabular}

Before sowing representative soil, samples were taken from the experimental soil sites in both seasons and prepared for analysis according to Jackson (1973). The soil chemical analysis is shown in Table 4.

Table 4. Chemical properties of the experimental soil sites

\begin{tabular}{|c|c|c|c|c|c|}
\hline Properties & $\begin{array}{r}\text { Sea } \\
2015 \\
\end{array}$ & $\begin{array}{l}\text { son } \\
2016 \\
\end{array}$ & Properties & $\begin{array}{r}\text { Sea } \\
2015\end{array}$ & $\begin{array}{l}\text { ason } \\
2016 \\
\end{array}$ \\
\hline$\overline{\mathrm{pH}}$ & 7.8 & 8.0 & Cations Meq/1 & & \\
\hline EC mmhos/ cm. & 0.26 & 0.54 & $\mathrm{Ca}^{++}$ & 1.33 & 1.28 \\
\hline Organic matter \% & 1.29 & 1.42 & $\mathrm{Mg}^{++}$ & 0.84 & 0.81 \\
\hline Total N (mg/100g) & 45.15 & 49.7 & $\mathrm{Na}^{+}$ & 3.40 & 3.20 \\
\hline Available N (ppm) & 21.3 & 28.7 & $\mathrm{~K}^{+}$ & 0.10 & 0.12 \\
\hline Available P (ppm) & 10.7 & 11.1 & & & \\
\hline Exchangeable K (ppm) & 312 & 306 & Allons Mreq/1 & & \\
\hline Available Fe (ppm) & 10.6 & 11.0 & $\mathrm{CO}_{3}^{--}$ & - & - \\
\hline Available Mn (ppm) & 3.8 & 2.9 & $\mathrm{HCO}_{3}^{-}$ & 0.90 & 0.82 \\
\hline Available Zn (ppm) & 1.1 & 0.90 & $\mathrm{Cl}^{-}$ & 2.41 & 2.38 \\
\hline Available Cu (ppm) & 3.22 & 3.0 & $\mathrm{SO}_{4}^{-}$ & 2.36 & 2.21 \\
\hline
\end{tabular}

The area of each experimental plot was $14 \mathrm{~m}^{2}$ (including five ridges each of $0.70 \mathrm{~m}$ wide $\mathrm{x} 4 \mathrm{~m}$ long).

Phosphorus fertilizer was applied as soil application at the rate of $22.5 \mathrm{~kg} \mathrm{P}_{2} \mathrm{O}_{5} /$ fed as super phosphate $\left(15.5 \% \mathrm{P}_{2} \mathrm{O}_{5}\right)$ during land preparation. Sowing date was done on 8 April after Egyptian clove "berseem" (Trifolium alexandrinum L.) in both seasons. The distance between hills was $25 \mathrm{~cm}$ with two plants/hill after thinning. Nitrogen fertilizer as ammonium nitrate $(33.5 \% \mathrm{~N})$ was applied at the rate of $45 \mathrm{~kg} \mathrm{~N} /$ fed in two equal portions, the first portion was added after thinning (before the first irrigation), while the second portion was applied before the second irrigation. Potassium fertilizer was applied as soil application at the rate of $24 \mathrm{~kg} \mathrm{~K}_{2} \mathrm{O}$ as potassium sulphate $\left(48 \% \mathrm{~K}_{2} \mathrm{O}\right)$ before the first irrigation. The other standard cultural practices were followed in both seasons.

\section{Studied characters:-}

Leaves chemical composition: After 107 days from sowing a sample of 10 leaves ( $4^{\text {th }}$ upper leaf) was randomly taken from plants of each plot to determine mineral elements (Nitrogen was determined by microkjeldahl, phosphorus by spectrometer, potassium by flame photometer), photosynthetic pigments (chlorophyll a, chlorophyll b, total chlorophyll (chl. a + chl. b) and carotenoids) by spectrophotometer model 390 , total carbohydrates and total sugars by spectrocolorimetrically as described by A.O.A.C. (1995), proline concentration (Bates et al., 1973) and determination of enzymes activity (peroxidase activity in optical density/g, O.D./g fresh weight after 2 minutes according to the method described by Fehrman and Dimond, 1967 and phenoloxidase activity in optical density/g (O.D./g fresh weight after 45 minutes) was measured by using the method described by Broesh, 1954 in both seasons.

Statistical analysis: The statistical analysis of the obtained data in the two seasons was done in each irrigation interval then the combined analysis for data from the three irrigation intervals was also done for each season according to Le Clerg et al. (1966) using M State-C microcomputer program and the treatments means were compared using LSD at 0.05 level of probability (Waller and Duncan, 1969).

\section{RESULTS AND DISCUSSION}

Averages of $\mathrm{N}, \mathrm{P}, \mathrm{K}$, photosynthetic pigments (chlorophyll a, chlorophyll b, total chlorophyll and carotenoids), total carbohydrates, total sugars and proline contents, peroxidase and phenoloxidase activity in cotton leaves as affected by irrigation intervals, Nano materials and natural materials as well as their interactions are shown in Tables 5-10.

\section{I-Effect of irrigation intervals:}

Irrigation intervals exhibited significant differences in leaves concentrations of nitrogen, phosphorus, potassium, chlorophyll a, total chlorophyll, total carbohydrates and total sugars in both seasons and chlorophyll $\mathrm{b}$ and carotenoids in the second season only, where the highest values of these traits in consideration resulted from irrigating cotton plants every 21 days followed by irrigation every 28 days and at last irrigation every 14 days (Tables 5 and 6). Irrigation intervals had a significant effect on proline content, peroxidase and phenoloxidase activity in cotton leaves in both seasons with one exception with regard to proline content in the second season, where the effect was not significant in the second season (Table 6). The minimum values of these traits in consideration were obtained from plants which irrigated every 21 days. However, the maximum values were obtained from irrigated plants every 14 days followed by irrigating plants every 28 days without significant differences between these two intervals in phenoloxidase and peroxidase activity in fresh leaves in the first season.

The positive effect of irrigated cotton plants every 21 days on percentages of $\mathrm{N}, \mathrm{P}$ and $\mathrm{K}$, photosynthetic pigments, i.e. chlorophyll a, chlorophyll $\mathrm{b}$, total chlorophyll and carotenoids, total carbohydrates and total sugars concentrations in leaves as compared with the other two irrigation intervals (every 14 and 28 days) is mainly due to that this period is proper for cotton cultivar Giza 86, where irrigation water applied less or more the optimum requirement of a crop adversely affects physiological and biochemical processes and results in limited absorption of the inorganic nutrients. In this concern, Garg (2003) reported that lowered absorption nutrients can result from interference in nutrient uptake and unloading mechanism and reduced transpiration flow. 
Attia, A. N. et al.

Table 5. Effect of irrigation intervals, Nano materials and natural materials as well as their interactions on leaves nitrogen, phosphorus, potassium, chlorophyll a, chlorophyll b, total chlorophyll and carotenoids contents in 2015 and 2016 seasons.

\begin{tabular}{|c|c|c|c|c|c|c|c|c|c|c|c|c|c|c|}
\hline \multirow{3}{*}{ Treatments } & \multicolumn{2}{|c|}{$\mathbf{N}(\%)$} & \multicolumn{2}{|c|}{$\mathbf{P}(\%)$} & \multicolumn{2}{|c|}{ K (\%) } & \multicolumn{2}{|c|}{$\begin{array}{c}\text { Chlorophyll a } \\
\text { (mg/g d.wt.) }\end{array}$} & \multicolumn{2}{|c|}{$\begin{array}{c}\text { Chlorophyll b } \\
\text { (mg/g d.wt.) }\end{array}$} & \multicolumn{2}{|c|}{$\begin{array}{l}\text { Total chlorophyll } \\
\text { (mg/g d.wt.) }\end{array}$} & \multicolumn{2}{|c|}{$\begin{array}{l}\text { Carotenoids } \\
\text { (mg/g d.wt.) }\end{array}$} \\
\hline & & & & & & & & Season & & & & & & \\
\hline & 2015 & 2016 & 2015 & 2016 & 2015 & 2016 & 2015 & 2016 & 2015 & 2016 & 2015 & 2016 & 2015 & 2016 \\
\hline \multicolumn{15}{|c|}{ A-Irrigation intervals } \\
\hline Every 14 days & 3.44 & 3.47 & 0.48 & 0.50 & 3.53 & 3.56 & 3.72 & 3.93 & 1.53 & 1.54 & 5.25 & 5.47 & 1.66 & 1.70 \\
\hline Every & 3.53 & .57 & 0.50 & 0.54 & 3.65 & & 3.83 & 4.0 & 1.57 & .58 & 40 & & 1.74 & 1.75 \\
\hline 8 days & 3.47 & 3.49 & 0.48 & 0.51 & 3.59 & 3. & 3.74 & 3.96 & 1.54 & 1.55 & 5.28 & & 1.70 & 1.71 \\
\hline LSD & 0.02 & 0.01 & 0.02 & 0.01 & 0.01 & 0.02 & 0.03 & 0.01 & NS & 0.01 & 0.03 & 1 & NS & 0.02 \\
\hline \multicolumn{15}{|c|}{ B - Spraying with Nano materials } \\
\hline Without & 3.43 & 3.46 & 0.42 & 0.45 & 3.54 & 3.56 & 3.53 & 3.70 & 1.32 & 1.35 & 4.85 & 5.05 & 1.43 & 1.42 \\
\hline Amino mineral & 3.47 & 3.50 & 0.49 & 0.52 & 3.58 & 3.60 & 3.82 & 3.99 & 1.61 & 1.58 & 5.43 & 5.5 & 1.80 & 1.81 \\
\hline Lithovit & 3.54 & 3.57 & 0.55 & 0.58 & 3.64 & 3.69 & 3.95 & 4.23 & 1.71 & 1.75 & 5.66 & 5.97 & 1.88 & 1.94 \\
\hline LSD at $5 \%$ & 0.02 & 0.01 & 0.01 & 0.01 & 0.03 & 0.02 & 0.07 & 0.03 & 0.02 & 0.01 & 0.08 & 0.03 & 0.12 & 0.01 \\
\hline \multicolumn{15}{|c|}{$\mathrm{C}$ - Spraying with natural materials } \\
\hline With & 3.44 & 3.46 & 0.44 & 0.46 & 3.54 & 3.54 & 3.65 & 3.85 & 1.50 & 1.51 & 5.1 & 5.3 & 1.6 & 1.68 \\
\hline Salicylic acid & & 3.51 & 0.49 & 0.53 & 3.59 & 3.6 & 3.77 & 3.98 & 1.57 & 1.5 & 5.34 & 5.5 & 1.70 & 1.71 \\
\hline Humic acid & 3.52 & 3.56 & 0.53 & 0.57 & 3.63 & 3.68 & 3.88 & 4.08 & 1.57 & 1.60 & 5.45 & 5.6 & 1.73 & 1.77 \\
\hline LSD at $5 \%$ & 0.01 & 0.01 & 0.01 & 0.01 & 0.01 & 0.02 & 0.03 & 0.02 & 0.01 & 0.01 & 0.04 & 0.02 & NS & 0.01 \\
\hline A X B & $*$ & $* *$ & NS & NS & $*$ & $*$ & NS & NS & NS & NS & NS & NS & NS & NS \\
\hline A X C & NS & $* *$ & NS & $*$ & NS & NS & NS & NS & NS & NS & NS & NS & NS & NS \\
\hline B X C & $*$ & $* *$ & $* *$ & $* *$ & NS & $* *$ & $* *$ & $* *$ & $* *$ & $* *$ & $* *$ & $* *$ & NS & $* *$ \\
\hline A X B X C & NS & NS & NS & * & NS & $*$ & NS & NS & NS & NS & NS & NS & NS & NS \\
\hline
\end{tabular}

$*$,** and NS, significant difference at $\mathrm{P}<0.05, \mathrm{P}<0.01$ and non-significant, respectively.

Table 6. Effect of irrigation intervals, Nano materials and natural materials as well as their interactions on leaves total sugars and total carbohydrates concentrations, peroxidase and phenoloxidase activity and proline content in 2015 and 2016 seasons.

\begin{tabular}{|c|c|c|c|c|c|c|c|c|c|c|}
\hline \multirow{3}{*}{ Treatments } & \multicolumn{2}{|c|}{$\begin{array}{l}\text { Total sugars } \\
\text { (mg/g d.wt.) }\end{array}$} & \multicolumn{2}{|c|}{$\begin{array}{c}\text { Total carbohydrates } \\
\text { (mg/g d.wt.) }\end{array}$} & \multicolumn{2}{|c|}{$\begin{array}{c}\text { Peroxidase } \\
\text { (O.D./g fresh weight) }\end{array}$} & \multicolumn{2}{|c|}{$\begin{array}{c}\text { Phenoloxidase } \\
\text { (O.D./g fresh weight) }\end{array}$} & \multicolumn{2}{|c|}{$\begin{array}{c}\text { Proline } \\
(\mu \mathrm{g} / \mathrm{g} \text { fresh weight })\end{array}$} \\
\hline & & & & & & ason & & & & \\
\hline & 2015 & 2016 & 2015 & 2016 & 2015 & 2016 & 2015 & 2016 & 2015 & 2016 \\
\hline \multicolumn{11}{|c|}{ A-Irrigation intervals } \\
\hline Every 14 days & 0.021 & 0.020 & 0.924 & 0.929 & 0.189 & 0.187 & 0.978 & 0.929 & 306.79 & 295.38 \\
\hline Every 21 days & 0.024 & 0.024 & 0.952 & 0.993 & 0.183 & 0.182 & 0.957 & 0.910 & 289.67 & 289.23 \\
\hline Every 28 days & 0.021 & 0.022 & 0.930 & 0.932 & 0.187 & 0.186 & 0.973 & 0.924 & 304.11 & 293.16 \\
\hline LSD at $5 \%$ & 0.002 & 0.001 & 0.013 & 0.007 & 0.002 & 0.001 & 0.005 & 0.001 & 2.03 & NS \\
\hline \multicolumn{11}{|c|}{ B -Spraying with Nano materials } \\
\hline Without & 0.020 & 0.021 & 0.904 & 0.925 & 0.194 & 0.191 & 0.988 & 0.947 & 319.01 & 313.05 \\
\hline Amino mineral & 0.022 & 0.022 & 0.932 & 0.950 & 0.187 & 0.185 & 0.970 & 0.922 & 302.17 & 294.86 \\
\hline Lithovit & 0.024 & 0.024 & 0.970 & 0.980 & 0.177 & 0.180 & 0.949 & 0.895 & 279.41 & 269.84 \\
\hline LSD at $5 \%$ & 0.002 & 0.001 & 0.009 & 0.001 & 0.001 & 0.001 & 0.001 & 0.001 & 2.89 & 6.32 \\
\hline \multicolumn{11}{|c|}{$\mathrm{C}-$ Spraying with natural materials } \\
\hline Without & 0.021 & 0.021 & 0.917 & 0.939 & 0.189 & 0.188 & 0.973 & 0.939 & 310.86 & 306.46 \\
\hline Salicylic acid & 0.022 & 0.022 & 0.937 & 0.952 & 0.187 & 0.185 & 0.970 & 0.924 & 301.04 & 291.95 \\
\hline Humic acid & 0.023 & 0.024 & 0.952 & 0.964 & 0.182 & 0.182 & 0.965 & 0.900 & 288.69 & 279.35 \\
\hline LSD at $5 \%$ & 0.001 & 0.001 & 0.006 & 0.003 & 0.001 & 0.001 & 0.002 & 0.001 & 1.80 & 7.52 \\
\hline \multicolumn{11}{|c|}{ Interactions } \\
\hline A X B & $* *$ & $* *$ & NS & $* *$ & $* *$ & $*$ & $* *$ & $* *$ & $*$ & NS \\
\hline A X C & $* *$ & NS & NS & $* *$ & $* *$ & NS & NS & NS & $* *$ & NS \\
\hline B X C & NS & $* *$ & $* *$ & $*$ & $* *$ & $* *$ & $* *$ & $* *$ & $* *$ & NS \\
\hline A X B X C & $*$ & NS & NS & $* *$ & $* *$ & NS & $* *$ & NS & $* *$ & NS \\
\hline
\end{tabular}

$*, * *$ and $\mathrm{NS}$, significant difference at $\mathrm{P}<0.05, \mathrm{P}<0.01$ and non-significant, respectively.

\section{2-Effect of Nano-materials:}

Nano materials treatments which included lithovit, amino mineral and control (untreated) significantly affected leaves concentrations of $\mathrm{N}, \mathrm{P}, \mathrm{K}$, photosynthetic pigments (chlorophyll a, chlorophyll b, total chlorophyll and carotenoids), total carbohydrates and total sugars in both seasons (Tables 5 and 6), in favor of plants which received $\mathrm{CO}_{2}$ as a Nano fertilizer as foliar spraying three times at a rate of $7.5 \mathrm{~g} / \mathrm{L}$ followed by those received amino mineral at $1 \mathrm{~cm}^{3} / \mathrm{L}$.
However, the lowest concentrations of these traits were obtained from the control treatment (without Nano materials application). In relation to proline content, peroxidase and phenoloxidase activity in leaves, Nano materials treatments gave significant effect in both seasons, in favor of lithovit where it significantly decreased these traits in consideration which indicates favorable conditions and reduces environmental stress effect (Table 6). However untreated plants recorded the highest values of these traits. The application of more 
$\mathrm{CO}_{2}$ can increase plant water use efficiency and result in less water use (Prior et al., 2011). Elevated $\mathrm{CO}_{2}$ stimulates photosynthesis leading to increased carbon (C) uptake and assimilation, thereby, as increasing total carbohydrates and total sugars concentration in leaves. However, as a result differences in $\mathrm{CO}_{2}$ use during photosynthesis, plants with a $\mathrm{C}_{3}$ photosynthetic pathway often exhibit greater growth response relative to those with a $\mathrm{C}_{4}$ pathway (Rogers et al., 1997; Prior et al., 2003 and Prior et al., 2011).

The positive effect on leaf chemical composition due to lithovit application as compared with amino mineral and control or due to amino mineral application as compared with control could be explained on the basis that:

1- Experimental soil being low in organic matter and available nitrogen (Table 4) and the supplied of lithovit or amino mineral provided leaves with NPK.

2- There are many factors that affect the availability of $\mathrm{P}$ in soils. The high clay content probably contributed to more fixation of $\mathrm{P}$ by clay minerals, leading to reduction of its availability (Mengel and Kirkby, 1987), and consequently lowers leaf $P$ content in untreated plants. $\mathrm{Mg}$ is an important Co-factor for the production of ATP (McCauley et al., 2009). It is very important for plants to absorb phosphorus,

3- There are many factors that affect the availability of $\mathrm{K}$ in soils. The high clay content probably contributed to more fixation of $\mathrm{K}$ by clay minerals, leading to reduction of its availability (Mengel and Kirkby, 1987), and consequently lowers leaf $\mathrm{K}$ content in untreated plants.

4-Such increases in chemical constituents as a result of foliar spray with lithovit or amino mineral may be due to their chemical constituents from macro and micro- nutrients (Tables 1 and 2) which affect positively on nutrient absorption and accumulation in plant cells.

5-A reference to Table 5 indicates that nitrogen, phosphorus and potassium percentages in leaves were significantly increased due to lithovit or amino mineral foliar application and thus improved flow of assimilates

6- A reference to Tables 1 and 2 indicates that nutrients content in lithovit or amino mineral were effective to increase photosynthesis pigments and enhance photosynthesis and hence more photosynthates.

The superiority of using lithovit on reducing proline content, peroxidase and phenoloxidase activity in cotton leaves (which induced proper conditions for plant growth and reflect on reduce water stress effect) may be attributed to the role of it as a source of calcium and carbonate which reduced inside plant cell to form carbon dioxide which accumulate in cells and increased the rate of photosynthetic assimilation and consequently increased total sugars and total carbohydrates. In this concern, Attia et al. (2016) reported that leaves chlorophyll a, b, total chlorophyll, carotenoids, N, P, K and total carbohydrates contents were significantly increased by using Nano-fertilizer (lithovit) and the inverse was true in leaf peroxidase activity and proline content.

\section{3-Effect of natural materials:}

Natural materials i.e. control (without), $5 \mathrm{~cm}^{3} / 1$ humic acid and 200 ppm salicylic acid exhibited significant effect on leaves concentrations of $\mathrm{N}, \mathrm{P}, \mathrm{K}$, chlorophyll a, chlorophyll $\mathrm{b}$, total chlorophyll, total carbohydrates and total sugars in both seasons and carotenoids in the second season only, where foliar feeding with humic acid $\left(5 \mathrm{~cm}^{3} / 1\right)$ gave the highest values of leaves concentrations of these traits in consideration followed by using salicylic acid as foliar spraying at a rate of $200 \mathrm{ppm}$ and the least values were obtained from untreated plants (without natural materials application). In contrary, applying $5 \mathrm{~cm}^{3} / \mathrm{g}$ humic acid resulted the lowest values of proline content, peroxidase and phenoloxidase activity in leaves in both seasons.

The positive effect of salicylic acid in reducing leaves proline content, leaves peroxidase and phenoloxidase activity compared to untreated plants (control) is mainly referred to:

1- salicylic acid applied in satisfactory concentration may temporarily lower the level of oxidative stress in plants, which acts as a hardening process improving the antioxidative capacity of the plants and helping to induce the synthesis of protective compounds (such as carotenoids). Enhancement of the level of chlorophyll and carotenoid pigments, photosynthetic rate, carboxylase activity of Rubisco and modification of the activity of some of the important enzymes - these are the roles assigned to salicylic acid (Hayat et al., 2007)

2-Salicylic acid alleviated the effect of drought stress and increased leaves relative water content which related to the role of salicylic acid in accumulation of compatible osmolytes in plants subjected to drought stress.

3- Salicylic acid plays critical roles in plant including respiration, stomatal movement, photo morphogenesis, and senescence. It is more important that salicylic acid has been demonstrated to be messenger involved in signal transduction in response to biotic and a biotic stress (Clark et al., 2000).

The positive effect of salicylic acid on carbohydrates and sugars concentrations in leaves is mainly related to:

Salicylic acid spray application increased $\mathrm{CO}_{2}$ uptake at chloroplast level rather than simple increases in stomatal opening, i.e. reduced resistance to entry of $\mathrm{CO}_{2}$ in the leaves.

The positive effect of salicylic acid on photosynthetic pigments compared to control treatment is mainly due to that salicylic acid applied in satisfactory concentration (200 ppm as recommended by other researchers included El- Ashmouny, 2014) may temporarily lower the level of oxidative stress in plants, which acts as a hardening process, improving the antioxidative capacity of the plants and helping to induce the synthesis of protective compounds (such as carotenoids), Hayat et al. (2007), also they reported that enhancement of the level of chlorophyll and carotenoid pigments are the roles assigned to salicylic acid. Vicent and Plasencia (2011) found that salicylic acid regulates 
the activities of various antioxidant enzymes such as, catalases, superoxide dismutases, and peroxidases etc., which induced plant defense against biotic and abiotic stresses and El-Ashmouny (2014) found that the highest values of carotenoids, total chlorophyll, chl. a and chl. b were obtained from the application of salicylic acid at $200 \mathrm{ppm}$ as compared with untreated plants.

The positive effect on leaf chemical composition due to the foliar feeding with humic acid is mainly referred to:

1)Application of humic acid in the form of actosol through foliar spraying increased the uptake of macro and micronutrients.

2)Humic acid (in the form of actosol) enriched the leaves with appreciable amount of $\mathrm{N}, \mathrm{P}, \mathrm{K}, \mathrm{Cl}, \mathrm{Ca}$, $\mathrm{Mg}, \mathrm{Fe}, \mathrm{Zn}, \mathrm{Mn}, \mathrm{Cu}$ and $\mathrm{B}$ (Table 3).

3)Boron in actosol affects the translocation of nitrogen and phosphorus (Stanley et al., 1995).

In this concern, Ahmed et al. (2013) indicated that humic acid increased chemical constitutes either inorganic, $\mathrm{N}, \mathrm{P}$ and $\mathrm{K}$, while $\mathrm{Na}, \mathrm{Cl}, \mathrm{Ca}$ and $\mathrm{Mg}$ were decreased, or organic constitutes e.g. proline, total free amino acids, total sugars, total soluble phenols, chlorophyll a, b, total chlorophyll and total carotenoids and Rady et al. (2016) reported that plants received humic acid showed improved nutritional status and photosynthetic efficiency compared to untreated plants.

\section{4-Effect of the interactions:}

Irrigation intervals and Nano materials interaction gave a significant effect on $\mathrm{N}, \mathrm{K}$ and total sugars concentrations in leaves in both seasons and on total carbohydrates concentration in the second season (Tables 5 and 6), in favor of irrigated cotton plants every 21 days and sprayed with lithovit at a rate of 7.5 $\mathrm{g} / \mathrm{l}$. However, the lowest concentrations of these traits were obtained by plants irrigated every 14 days without Nano materials application (Table 7). This interaction gave insignificant effect on leaves photosynthetic pigments i.e. chlorophyll a, chlorophyll b, total chlorophyll and carotenoids contents in both seasons. The interaction of irrigated cotton plants every 14 days without Nano materials applications surpassed significantly the other interaction treatments and gave the highest values of proline content, peroxidase and phenoloxidase activity in cotton leaves in both seasons with an exception with regard to proline concentration in leaves, where this interaction gave a significant effect in the first season only.

Irrigation intervals and natural materials interaction had a significant effect on concentrations of nitrogen, phosphorus, total sugars and total carbohydrates in leaves in one season only (Tables 5 and 6), in favor of plants irrigated every 21 days and received humic acid at a rate of $5 \mathrm{~cm}^{3} / 1$. However, the lowest values resulted from plants irrigated every 14 days without application with natural materials. The interaction of irrigated cotton plants every 21 days and received humic acid as foliar spraying at the rate of $5 \mathrm{~cm}^{3} / 1$ gave the lowest values of proline content and peroxidase activity in cotton leaves in the first season (Table 8).

The effect of the interaction between Nano materials treatments and natural materials treatments was significant with regard to $\mathrm{N}, \mathrm{P}$, chlorophyll a, chlorophyll $\mathrm{b}$, total chlorophyll and total carbohydrates contents in leaves in both seasons and $\mathrm{K}$, carotenoids and total sugars in leaves in the second season only (Tables 5 and 6). Data in Table 9 show that foliar $\mathrm{CO}_{2}$ as a Nano fertilizer at a rate of $7.5 \mathrm{~g} / \mathrm{l}$ and spraying humic acid at a rate of $5 \mathrm{~cm}^{3} / 1$ produced the highest values of these traits with one exception, where plants received lithovit and salsylic acid produced the highest value of chlorophyll $b$ in the first season. However, untreated plants (without Nano or natural materials application) produced the lowest values of these traits in consideration with one exception, where untreated plants (without Nano materials application) which received salicylic acid at a rate of $200 \mathrm{ppm}$ produced the lowest value of leaves carotenoids concentration. In the contrary, this interaction treatment gave the highest concentration of leaf proline in the first season and peroxidase and phenoloxidase activity in cotton leaves in both seasons.

Table 7. Averages of nitrogen and potassium percentages, total sugars and total carbohydrates concentrations, peroxidase and phenoloxidase activity and proline content in leaves as affected by the interaction between irrigation intervals and Nano materials.

\begin{tabular}{|c|c|c|c|c|c|c|c|c|c|c|c|c|c|}
\hline \multicolumn{2}{|c|}{ Treatments } & \multicolumn{2}{|c|}{ N (\%) } & \multicolumn{2}{|c|}{ K (\%) } & \multicolumn{2}{|c|}{$\begin{array}{l}\text { Total sugars } \\
\text { (mg/g d.wt.) }\end{array}$} & \multirow{2}{*}{$\begin{array}{c}\begin{array}{c}\text { Total } \\
\text { carbohydrate } \\
\text { (mg/g d.wt.) }\end{array} \\
\text { Season }\end{array}$} & \multicolumn{2}{|c|}{$\begin{array}{c}\text { Peroxidase } \\
\text { (O.D./g fresh } \\
\text { weight) }\end{array}$} & \multicolumn{2}{|c|}{$\begin{array}{c}\text { Phenoloxidase } \\
\text { ( O.D./g fresh } \\
\text { weight) }\end{array}$} & \multirow[t]{2}{*}{$\begin{array}{c}\text { Proline } \\
(\mu \mathrm{g} \mathrm{l} / \mathrm{g} \\
\text { fresh wt. }) \\
\end{array}$} \\
\hline \multirow{2}{*}{$\begin{array}{l}\text { Irrigation } \\
\text { intervals }\end{array}$} & \multirow{2}{*}{ Nano materials } & & & & & & & & & & & & \\
\hline & & 2015 & 2016 & 2015 & 2016 & 2015 & 2016 & 2016 & 2015 & 2016 & 2015 & 2016 & 2015 \\
\hline \multirow{3}{*}{$\begin{array}{l}\text { Every } 14 \\
\text { days }\end{array}$} & Without & 3.38 & 3.42 & 3.47 & 3.48 & & & 0.896 & 0.196 & 0.193 & 0.992 & 0.951 & 325.59 \\
\hline & Amino mineral & 3.43 & 3.47 & 3.52 & 3.55 & 0.021 & 0.020 & 0.924 & 0.189 & 0.187 & 0.980 & 0.931 & 307.17 \\
\hline & Lithovit & 3.50 & 3.53 & 3.60 & 3.66 & 0.023 & 0.022 & 0.968 & 0.181 & 0.182 & 0.961 & 0.906 & 287.61 \\
\hline \multirow{3}{*}{$\begin{array}{l}\text { Every } 21 \\
\text { days }\end{array}$} & Without & 3.50 & 3.54 & 3.62 & 3.63 & 0.022 & 0.023 & 0.980 & 0.191 & 0.188 & 0.980 & 0.939 & 308.49 \\
\hline & Amino mineral & 3.53 & 3.55 & 3.64 & 3.66 & 0.025 & 0.024 & 0.999 & 0.185 & 0.182 & 0.957 & 0.910 & 292.61 \\
\hline & Lithovit & 3.58 & 3.63 & 3.68 & 3.73 & 0.027 & 0.026 & 1.002 & 0.173 & 0.176 & 0.934 & 0.880 & 267.93 \\
\hline \multirow{3}{*}{$\begin{array}{l}\text { Every } 28 \\
\text { days }\end{array}$} & Without & 3.41 & 3.43 & 3.55 & 3.56 & 0.020 & 0.020 & 0.899 & 0.194 & 0.191 & 0.992 & 0.950 & 322.95 \\
\hline & Amino mineral & 3.46 & 3.49 & 3.57 & 3.60 & 0.021 & 0.021 & 0.927 & 0.188 & 0.186 & 0.974 & 0.925 & 306.71 \\
\hline & Lithovit & 3.53 & 3.55 & 3.64 & 3.67 & 0.023 & 0.023 & 0.970 & 0.178 & 0.180 & 0.953 & 0.895 & 282.69 \\
\hline \multicolumn{2}{|c|}{ LSD at $5 \%$} & 0.02 & 0.01 & 0.03 & 0.06 & 0.003 & 0.001 & 0.008 & 0.003 & 0.001 & 0.001 & 0.001 & 2.63 \\
\hline
\end{tabular}


The second order interaction among irrigation intervals, Nano materials treatments and natural materials treatments had a significant effect on concentrations of $\mathrm{P}, \mathrm{K}$ and total carbohydrates in leaves in $2^{\text {nd }}$ season (2016) and total sugars in the $1^{\text {st }}$ season (2015) as shown in Tables 5 and 6. Data in Table 10 show that plants irrigated every 21 days which received $\mathrm{CO}_{2}$ as a Nano fertilizer (in the form of lithovit) at a rate of $7.5 \mathrm{~g} / \mathrm{L}$ in combination with $5 \mathrm{~cm}^{3} / \mathrm{L}$ humic acid led to a significant increase in $\mathrm{P}, \mathrm{K}$, total sugars and total carbohydrates concentrations in leaves compared to the other interaction treatments. However, cotton plants irrigated every 14 days without application with Nano or natural treatments produced the lowest concentrations. Also, plants irrigated every 21 days which received $\mathrm{CO}_{2}$ as a Nano fertilizer (in the form of lithovit) at a rate of $7.5 \mathrm{~g} / \mathrm{L}$ in combination with 5 $\mathrm{cm} 3 / \mathrm{L}$ humic acid gave the lowest values of proline content, peroxidase and phenoloxidase activity in cotton leaves in the first season, which induced proper conditions for plant growth and reflect on reduce water stress effect. Photosynthetic pigments in leaves were insignificantly affected by this interaction in both seasons. The positive effect on leaf chemical composition due to the second order interaction, i.e. irrigation cotton plants every 21 days in combination with lithovit at the rate of $7.5 \mathrm{~g} / \mathrm{L}$ and foliar feeding spraying with $5 \mathrm{~cm}^{3} / \mathrm{L}$ humic acid three times (at the squaring stage, flowering initiation and at the top of flowering) is mainly referred to: The main role of macro and micro nutrients in lithovit or humic acid. In this regard, Reddy et al. (1997) found that photosynthesis increased due to doubled $\mathrm{CO}_{2}$ under a range of water stress.

Table 8. Averages of nitrogen, phosphorus percentages, total sugars and total carbohydrates concentrations, peroxidase activity and proline content in leaves as affected by the interaction between irrigation intervals and natural materials.

\begin{tabular}{|c|c|c|c|c|c|c|c|}
\hline Treatments & & $\mathbf{N}(\%)$ & $\mathbf{P}(\%)$ & $\begin{array}{l}\text { Total sugars } \\
\text { (mg/g d. wt.) }\end{array}$ & $\begin{array}{c}\text { Total carbohydrates } \\
\text { (mg/g d.wt.) }\end{array}$ & $\begin{array}{c}\text { Peroxidase } \\
\text { (O.D./g fresh weight) }\end{array}$ & $\begin{array}{c}\begin{array}{c}\text { Proline } \\
(\mu \mathrm{g} / \mathrm{g} \text { fresh wt.) }\end{array} \\
\end{array}$ \\
\hline \multirow{2}{*}{$\begin{array}{l}\text { Irrigation } \\
\text { intervals }\end{array}$} & \multirow{2}{*}{ Natural materials } & \multicolumn{6}{|c|}{ Season } \\
\hline & & 2016 & 2016 & 2015 & 2016 & 2015 & 2015 \\
\hline \multirow{3}{*}{$\begin{array}{l}\text { Every } 14 \\
\text { days }\end{array}$} & Without & 3.43 & 0.45 & 0.020 & 0.914 & 0.191 & 316.43 \\
\hline & Salicylic acid & 3.48 & 0.51 & 0.021 & 0.927 & 0.189 & 307.75 \\
\hline & Humic acid & 3.51 & 0.54 & 0.022 & 0.946 & 0.185 & 296.20 \\
\hline \multirow{3}{*}{$\begin{array}{l}\text { Every } 21 \\
\text { days }\end{array}$} & Without & 3.50 & 0.48 & 0.023 & 0.983 & 0.187 & 299.76 \\
\hline & Salicylic acid & 3.58 & 0.55 & 0.025 & 0.998 & 0.184 & 292.22 \\
\hline & Humic acid & 3.64 & 0.60 & 0.026 & 0.999 & 0.177 & 277.04 \\
\hline \multirow{3}{*}{$\begin{array}{l}\text { Every } 28 \\
\text { days }\end{array}$} & Without & 3.45 & 0.45 & 0.021 & 0.919 & 0.190 & 316.38 \\
\hline & Salicylic acid & 3.49 & 0.53 & 0.021 & 0.930 & 0.188 & 303.14 \\
\hline & Humic acid & 3.53 & 0.56 & 0.022 & 0.948 & 0.183 & 292.83 \\
\hline LSD at $5 \%$ & & 0.02 & 0.01 & 0.003 & 0.005 & 0.001 & 3.11 \\
\hline
\end{tabular}

Table 9. Averages of nitrogen, phosphorus and potassium percentages, total sugars, total carbohydrates, chlorophyll a, chlorophyll b, total chlorophyll and carotenoids concentrations, peroxidase and phenoloxidase activity and proline content in leaves as affected by the interaction between Nano materials and natural materials.

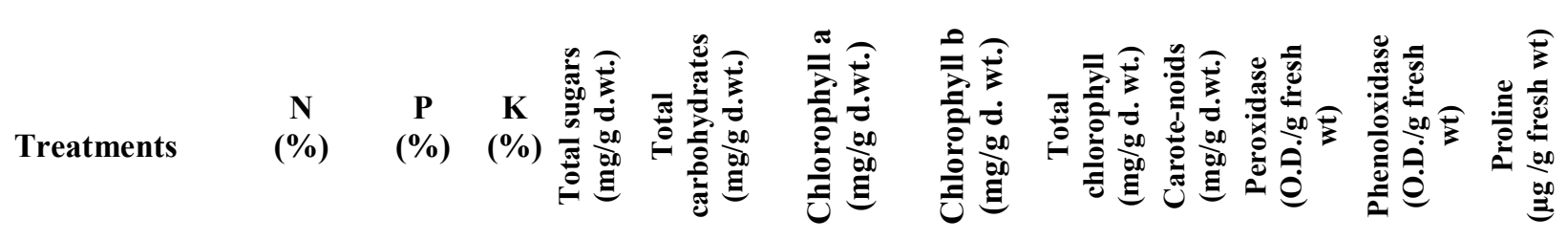

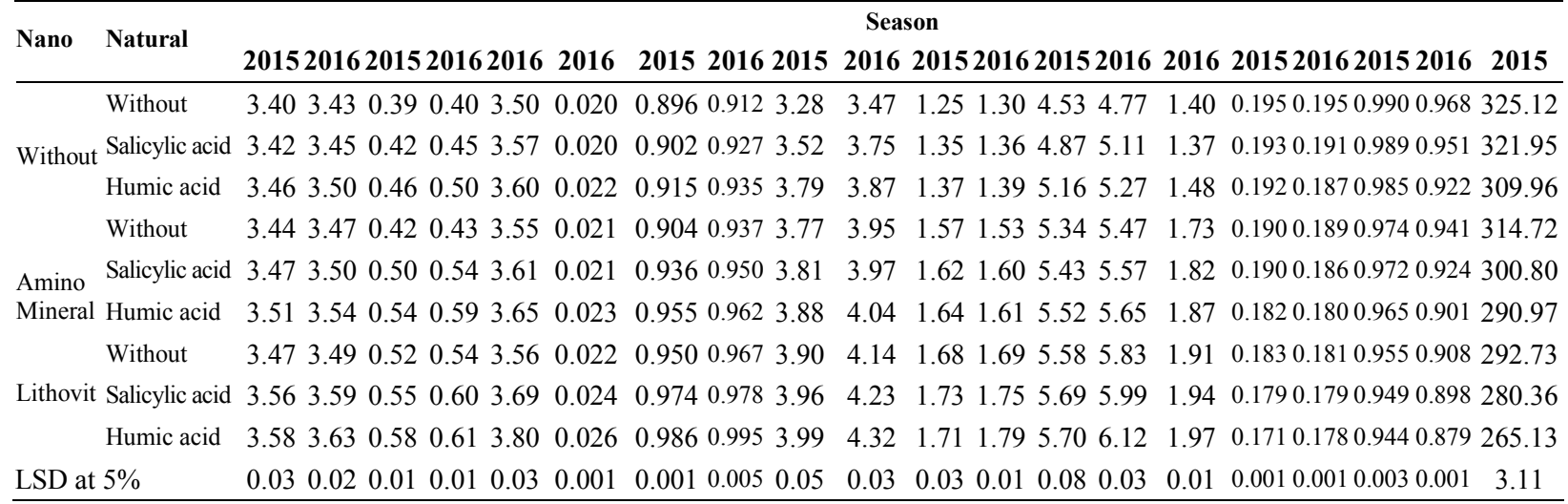


Table 10. Averages of phosphorus, potassium, total carbohydrates and total sugars concentrations, peroxidase and phenoloxidase activity and proline content in leaves as affected by the interaction among irrigation intervals, Nano materials and natural materials

\begin{tabular}{|c|c|c|c|c|c|c|c|c|c|}
\hline \multirow[t]{2}{*}{$\begin{array}{l}\text { Irrigation } \\
\text { intervals }\end{array}$} & \multirow[t]{2}{*}{$\begin{array}{c}\text { Nano } \\
\text { materials }\end{array}$} & \multirow[t]{2}{*}{$\begin{array}{l}\text { Natural } \\
\text { materials }\end{array}$} & P \% & K \% & $\begin{array}{c}\text { Total } \\
\text { carbohydrates } \\
(\mathrm{mg} / \mathrm{g} \mathrm{dw})\end{array}$ & $\begin{array}{c}\text { Total } \\
\text { Sugars } \\
(\mathrm{mg} / \mathrm{g} \text { dw. })\end{array}$ & $\begin{array}{c}\text { Peroxidase } \\
\text { (O.D./g } \\
\text { fresh wt) }\end{array}$ & $\begin{array}{c}\text { Phenoloxidase } \\
\text { (O.D./g } \\
\text { fresh wt) }\end{array}$ & \multirow[t]{2}{*}{$\begin{array}{c}\text { Proline } \\
(\mu g / g \\
\text { fresh wt })\end{array}$} \\
\hline & & & \multicolumn{3}{|c|}{2016 season } & \multicolumn{3}{|c|}{2015 season } & \\
\hline \multirow{3}{*}{$\begin{array}{l}\text { Every } 14 \\
\text { days }\end{array}$} & Without & \multirow{9}{*}{ Without } & 0.38 & 3.44 & 0.890 & 0.019 & 0.198 & 0.997 & 332.00 \\
\hline & Amino mineral & & 0.43 & 3.49 & 0.904 & 0.020 & 0.192 & 0.983 & 321.46 \\
\hline & Lithovit & & 0.54 & 3.51 & 0.949 & 0.022 & 0.185 & 0.965 & 295.82 \\
\hline \multirow{3}{*}{$\begin{array}{l}\text { Every } 21 \\
\text { days }\end{array}$} & Without & & 0.44 & 3.54 & 0.950 & 0.021 & 0.193 & 0.981 & 316.05 \\
\hline & Amino mineral & & 0.45 & 3.59 & 0.998 & 0.023 & 0.187 & 0.961 & 300.96 \\
\hline & Lithovit & & 0.55 & 3.60 & 1.000 & 0.025 & 0.181 & 0.942 & 282.29 \\
\hline \multirow{3}{*}{$\begin{array}{l}\text { Every } 28 \\
\text { days }\end{array}$} & Without & & 0.40 & 3.50 & 0.897 & 0.020 & 0.196 & 0.994 & 327.30 \\
\hline & Amino mineral & & 0.42 & 3.57 & 0.908 & 0.021 & 0.190 & 0.978 & 321.74 \\
\hline & Lithovit & & 0.54 & 3.57 & 0.951 & 0.022 & 0.184 & 0.959 & 300.09 \\
\hline \multirow{3}{*}{$\begin{array}{l}\text { Every } 14 \\
\text { days }\end{array}$} & Without & \multirow{9}{*}{$\begin{array}{l}\text { Salicylic } \\
\text { acid }\end{array}$} & 0.44 & 3.49 & 0.892 & 0.020 & 0.196 & 0.994 & 327.57 \\
\hline & Amino mineral & & 0.53 & 3.57 & 0.925 & 0.021 & 0.192 & 0.981 & 306.04 \\
\hline & Lithovit & & 0.58 & 3.65 & 0.965 & 0.023 & 0.181 & 0.962 & 289.64 \\
\hline \multirow{3}{*}{$\begin{array}{l}\text { Every } 21 \\
\text { days }\end{array}$} & Without & & 0.47 & 3.65 & 0.995 & 0.021 & 0.191 & 0.98 & 312.11 \\
\hline & Amino mineral & & 0.56 & 3.68 & 0.998 & 0.025 & 0.187 & 0.959 & 293.24 \\
\hline & Lithovit & & 0.62 & 3.77 & 1.002 & 0.028 & 0.176 & 0.933 & 271.32 \\
\hline \multirow{3}{*}{$\begin{array}{l}\text { Every } 28 \\
\text { days }\end{array}$} & Without & & 0.45 & 3.59 & 0.895 & 0.021 & 0.194 & 0.993 & 326.17 \\
\hline & Amino mineral & & 0.54 & 3.60 & 0.928 & 0.021 & 0.191 & 0.976 & 303.12 \\
\hline & Lithovit & & 0.60 & 3.66 & 0.967 & 0.023 & 0.179 & 0.952 & 280.13 \\
\hline \multirow{3}{*}{$\begin{array}{l}\text { Every } 14 \\
\text { days }\end{array}$} & Without & \multirow{10}{*}{$\begin{array}{l}\text { Humic } \\
\text { acid }\end{array}$} & 0.48 & 3.51 & 0.905 & 0.020 & 0.194 & 0.986 & 317.21 \\
\hline & Amino mineral & & 0.57 & 3.60 & 0.943 & 0.022 & 0.184 & 0.975 & 294.02 \\
\hline & Lithovit & & 0.57 & 3.82 & 0.989 & 0.024 & 0.178 & 0.956 & 277.37 \\
\hline \multirow{3}{*}{$\begin{array}{l}\text { Every } 21 \\
\text { days }\end{array}$} & Without & & 0.51 & 3.70 & 0.994 & 0.024 & 0.190 & 0.981 & 297.29 \\
\hline & Amino mineral & & 0.62 & 3.71 & 0.999 & 0.026 & 0.180 & 0.952 & 283.65 \\
\hline & Lithovit & & 0.66 & 3.82 & 1.004 & 0.029 & 0.163 & 0.927 & 250.18 \\
\hline \multirow{3}{*}{$\begin{array}{l}\text { Every } 28 \\
\text { days }\end{array}$} & Without & & 0.51 & 3.60 & 0.906 & 0.021 & 0.193 & 0.989 & 315.31 \\
\hline & Amino mineral & & 0.58 & 3.65 & 0.945 & 0.022 & 0.184 & 0.968 & 295.26 \\
\hline & Lithovit & & 0.61 & 3.78 & 0.993 & 0.024 & 0.172 & 0.949 & 267.84 \\
\hline LSD at 0.05 & & & 0.02 & 0.05 & 0.009 & 0.005 & 0.002 & 0.005 & 5.39 \\
\hline
\end{tabular}

\section{REFERENCES}

A.O.A.C. (1995). Association of Official Agriculture Chemists. Official Methods of Analysis. $16^{\text {th }} \mathrm{Ed}$. A.O.A.C. Virginia, D.C., USA.

Ahmed, A.H.; E. Darwish; S.A.F. Hamoda and M.G. Alobaidy (2013). Effect of putrescence and humic acid on growth, yield and chemical composition of cotton plants grown under saline soil conditions. American-Eurasian J. Agric. \& Environ. Sci., 13 (4): 479-497.

Attia, A. N. E.; M. H. El-Hendi; S. A. F. Hamoda and Shiamaa O. S. El-Sayed (2016). Effect of Nanofertilizer (Lithovit) and potassium on leaves chemical composition of Egyptian cotton under different planting dates. J. Plant Production, Mansoura Univ., 7 (9): 935 - 942.

Bates, L. S.; R. P. Waldem and I. D. Teare (1973). Rapid determination of free proline under water stress studies. Plant and Soil, 39: 205 - 207.

Broesh, S. (1954). Colorimetric assay of phenoloxidase. Bull. Soc. Chem., Biol., 36: 711-713.

Clark, A.J., W. Landolt, J.B. Bucher, and R.J. Strasser (2000). Beech (Fagus sylvatica) response to ozone exposure assessed with a chlorophyll a fluorescence performance index. Environ. Poll.,109: 501-507.
El - Ashmouny, A. A. M. (2014). Effect of some bioregulators on cotton yield grown under different planting dates and irrigation intervals. Ph. D. Thesis, Fac. of Agric., Minufiya Univ.

El-Sayed, S. O. S. (2012). Effect of NPK rates and humic acid treatments on growth, yield and fiber quality of Egyptian cotton. M.Sc Thesis Fac. of Agric. Mansoura Univ.

Fehrman, H. and A. E. Dimond (1967). Peroxidase activity and phytophthora resistance in different organs of the potato. Plant Pathology, 57: 69-72.

Garg, B.K. (2003). Nutrient uptake and management under drought: nutrient-moisture interaction. Current Agriculture, 27: 1-8.

Hayat, S.; B. Ali and A. Ahmad (2007). Salicylic acid: biosynthesis, metabolism and physiological role in plants. In: Hayat S, Ahmad A (eds) Salicylic acid: a plant hormone, Springer, Dordrecht, The Netherlands pp. 1-14.

Jackson, M.L. (1973). "Soil Chemical Analysis", Prentice Hall of India Private Limited, New Delhi.

Jalota, S. K.; A. G. B. S. Sood and B. U. Chahal (2006). Crop water productivity of cotton (Gossypium hirsutum L.)-wheat (Triticum aestivum L.) system as influenced by deficit irrigation, soil texture and precipitation. Agric. Water Manage., 84:137-146. 
Le Clerg, E. L.; W. H. Leonard and A. G. Clark (1966). Field Plot Technique. Burgess Pub. Co. Minneapolis, U.S.A.

McCauley, A; C. Jones and J. Jacobsen (2009): Plant nutrient functions and deficiency and Toxicity symptoms. Nutrient Management, Montana State Univ., Extension 4449 - 9 May 2009.

Mengel, K. and E. Kirkby (1987). Principles of plant nutrition. International Potash Institute P. O. Box. Ch. 3048 Worblan Fen.Bern, Switzerland.

Pereira, L. S.; P. Paredes; E. D. Eholpankulov; O. P. Inchenkova, P. R. Teodoro and M. G. Horst (2009). Irrigation scheduling strategies for cotton to cope with water scarcity in the Fergana Valley, Central Asia. Agric. Water Manage., 96:723-735.

Prior, S.A.; G. Brett; S. Runion; C. Marble; H. H. Rogers; C. H. Gilliam and H. A. Torbert (2011). Review of elevated atmospheric $\mathrm{CO}_{2}$ effects on plant growth and water relations: Implications for horticulture. Hort. science,46(2): 158-162.

Prior, S.A.; H.A. Torbert; G.B. Runionand H.H. Rogers (2003). Implications of elevated $\mathrm{CO}_{2}$ induced changes in agroecosystem productivity. J. Crop Prod., 8: 217-244.

Rady, M. T.; A. Abd El-Mageed; H. A. Abdulrahman and A. H. Mahdi (2016). Humic acid application improves field performance of cotton (Gossypium barbadense L.) under saline conditions. J. of Animal \& Plant Sci., 26(2): 487-493.
Reddy, K. R.; H. F. Hodges and J. M. McKinion (1997). Water and nutrient deficits, crop yields and climate change. World Resour Rev., 10: 23 - 43.

Rogers, H.H.; G.B. Runion; S.V. Krupa and S.A. Prior (1997). Plant responses to atmospheric $\mathrm{CO}_{2}$ enrichment: Implications in root-soil-microbe interactions, p.1-34. In: Allen, L.H., Jr., M.B. Kirkham, D.M. Olszyk and C.E. Whitman (eds.). Advances in carbon dioxide effects research. ASA Special Publication No. 61. ASA, CSSA, and SSSA, Madison, WI.

Stanley, D.W.; M.C. Bourne; A.P. Stone and W.V. Wismer (1995). Low temperature blanching effects of chemistry, firmness and structure of canned green beans and carrots. Food Sci., 60: 327-333.

Tang, L.; Y. Li and J. Zhang (2005). Physiological and yield responses of cotton under partial root zone irrigation. Field Crops Res., 94:214-223.

Vicent, M. R. S. and J. Plasencia (2011). Salicylic acid beyond defence: its role in plant growth and development. J. Exp. Bot., 62: 3321-3338.

Waller, R. A. and D. B. Duncan (1969). A bays rule for the symmetric multiple comparison problems. J. Amer. Stat. Assoc., 64:1485-1503.

\section{تأثير الرش الورقى بالمواد النانو والطبيعية تحت ظروف الاجهاد المائى على التركيب الكيماوى لاوراق القطن

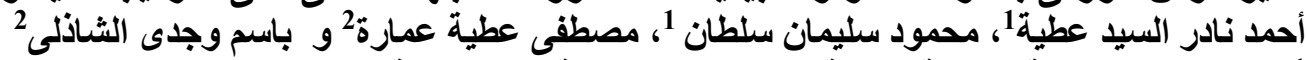

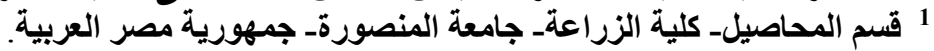

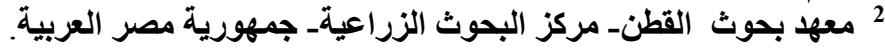

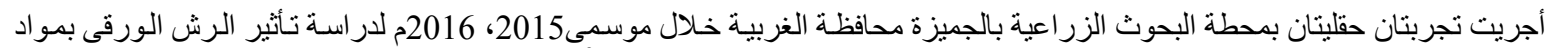

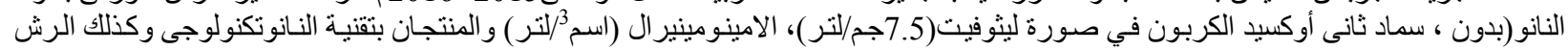

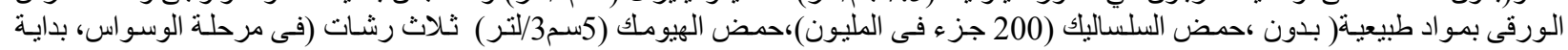

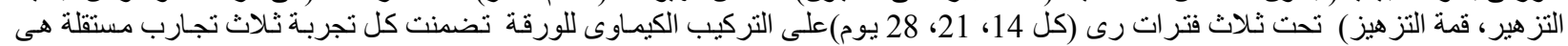

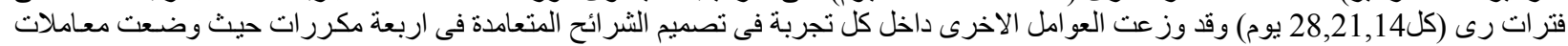

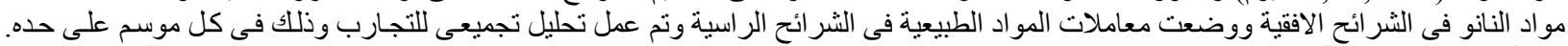

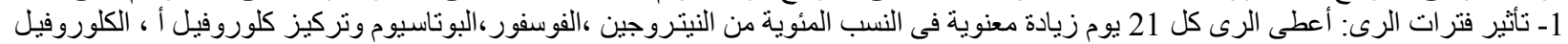

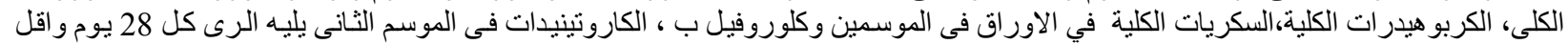

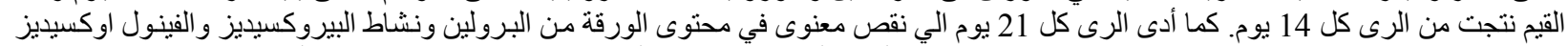

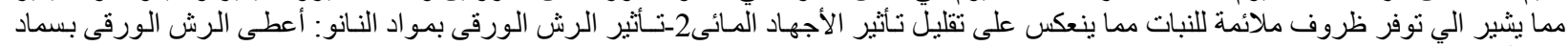

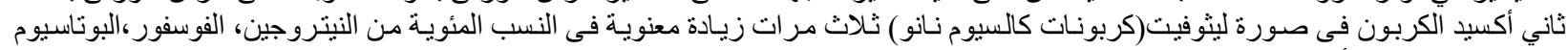

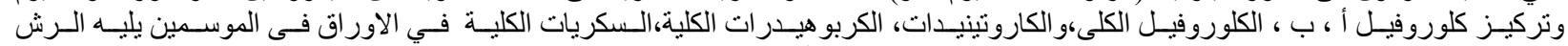

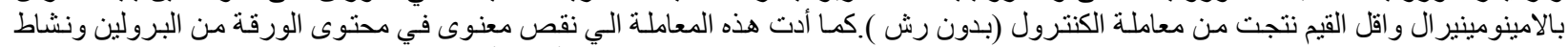

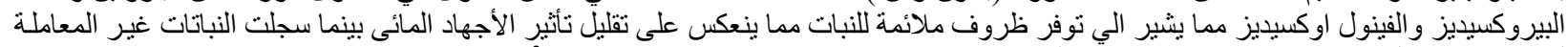

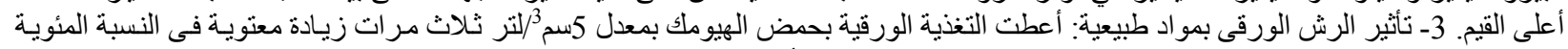

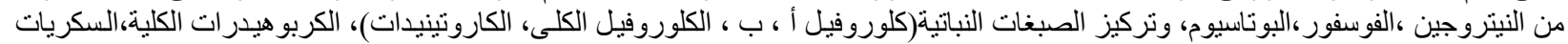

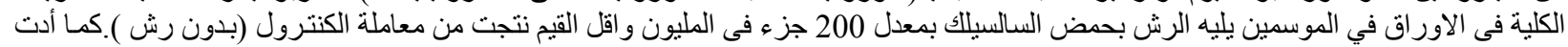

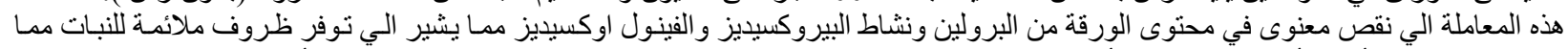

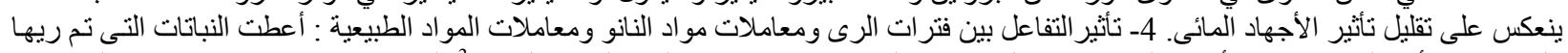

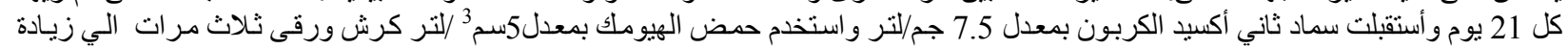

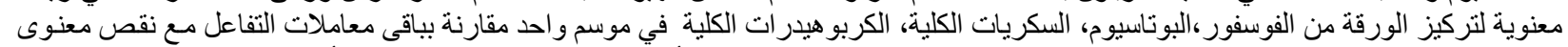

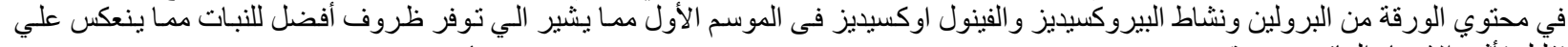

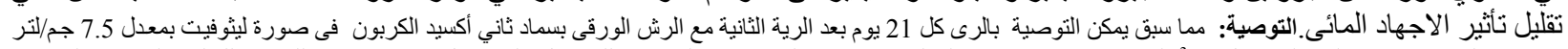

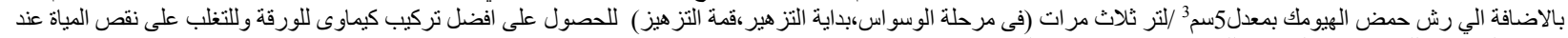
نهايات الترع وكنلك عند ندرة المياه وذلك تحت ظروف منطقة الجميزة. 